\title{
EDITORIAL RELIGIÓN, DEPORTE Y ESPECTÁCULO
}

Por lo tanto, creo haber tenido razón al haber intentado, desde el principio del renacimiento olimpico, reavivar una conciencia religiosa.

Pierre de Frédy, Barón de Coubertin.

Desde la época de la primera dinastía egipcia, hasta el periodo Ptolemaico, la más importante celebración de los soberanos egipcios fue el Heb Seb, la fiesta de renovación real, donde la fuerza y energía del faraón eran renovadas. La parte más importante del festival era la carrera ritual llevada a cabo por el soberano, en la que exhibía su fortaleza física, que le hacía digno de seguir gobernando. El faraón demostraba en esta festividad su hombría; incluso la reina Hatshepsut portará la barba postiza utilizada en las ocasiones más solemnes, identificándose de este modo con Osiris. Virilidad, poder y religión van unidos.

Entre las actividades deportivas profusamente representadas en Egipto encontramos la pelea, la caza con arco, luchas entre barcos de pescadores, o combates de esgrima con bastones con marcado contenido ritual. Se trata de actividades vinculadas a la guerra y al ámbito masculino que pueden contrastar con actividades femeninas, de carácter más pacífico, como la danza, relacionada ritualmente con la fertilidad y con la diosa Hathor.

También en el Próximo Oriente encontramos manifestaciones deportivas de carácter bélico, pudiéndose destacar alguna fuente como el manual de hipología más antigua conservado, hallado en las ruinas de Hattusa (datado en torno al 1400 a. C., durante el Reino Nuevo Hitita), firmado por Kikkuli, de la tierra de Mitani. La técnica de equitación fue fundamental para la guerra y para el dominio hitita.

Ya en el mundo antiguo, como vemos, el deporte nos habla de la guerra y de la paz, de lo masculino y lo femenino, de la religión y el espectáculo. De las relaciones sociales, en definitiva. 
Hemos querido focalizar este monográfico en las relaciones que se establecen entre el deporte y la religión. Abundan los estudios realizados desde las perspectivas sociológica y antropológica acerca de la relación entre deporte y religión, especialmente en lo que se refiere al mundo actual, pero lo que se plantea en este número de El Futuro del Pasado es trabajar sobre la perspectiva histórica de esa relación, desde la Antigüedad hasta nuestros días, pasando por diversas épocas, países, civilizaciones, culturas y religiones, con sus diferentes concepciones de deportes y espectáculos deportivos, y las variadas expresiones de la vivencia pública o privada del hecho religioso asociado a las manifestaciones deportivas en la historia.

A nadie se le escapa la enorme importancia que el deporte tiene en nuestra globalizada sociedad actual, que muchos consideran desproporcionada: por una parte, el deporte como ejercicio físico en relación con la creciente preocupación por la salud personal en el marco de unos hábitos donde el sedentarismo se instala cada vez más; por otra parte, el deporte de competición, como entretenimiento y, por supuesto, como espectáculo, y en muchas ocasiones, espectáculo de masas.

Esa relevancia tiene sus orígenes en el mundo clásico, aunque como se ha señalado existen testimonios de deportes mucho antes de la aparición de las civilizaciones clásicas. Y esos orígenes tienen una doble vertiente: la helena y la romana, igualmente importantes aunque con connotaciones netamente diferentes.

Ya en la civilización minoica, de carácter prehelénico, los frescos restaurados del palacio de Cnosos nos muestran escenas marítimas, típicas también de otras culturas isleñas mediterráneas -delfines, motivos decorativos en espiral que simulan el oleaje...-, pero también escenas deportivas, como las relacionadas con los juegos de toros y el boxeo.

Por una parte, encontramos en Creta los testimonios iconográficos más antiguos de los juegos relacionados con los toros. En las escenas vemos saltos, recortes y acrobacias sobre estos animales, que se hallan en el origen del actual espectáculo de la tauromaquia, extendido especialmente en España, sur de Francia, Portugal y varios países de Centroamérica y Suramérica. Pero el aspecto esencial de la tauromaquia, la muerte del animal, como su propio nombre indica, proviene de los espectáculos romanos que incluían en ocasiones la lucha entre gladiadores especializados y toros, en el marco de los munera o juegos gladiatorios con bestias, tal y como atestiguan inscripciones halladas en la ciudad romana de Pompeya. Aunque bien es cierto que es en Creta donde tiene lugar, míticamente, la muerte de Asterión, el Minotauro (el Toro de Minos), a manos del héroe Teseo.

Si consideramos la civilización minoica como pacífica, como tradicionalmente se ha interpretado, el deporte y la competición podrían haber actuado, con efectos pacificadores, como canalizadores de la energía y de la agresividad, una agresividad que se 
muestra en escenas representadas en frescos, donde vemos manifestaciones de pugilato como la del ritón de Hagia Triada, donde algunos combatientes portan casco militar, o las escenas de boxeo entre niños que aparecen en Tera. La educación como agente socializador fundamental tiene sin duda una estrecha vinculación con el deporte. Si el pugilato y la tauromaquia servían (y/o sirven) de catarsis o de impulsores de la violencia es algo que queda abierto para el debate.

Si andamos en el tiempo hasta la época arcaica griega vemos cómo habían comenzado en la parte occidental del Peloponeso los juegos del santuario de Olimpia, en donde sabemos que existió un gran altar de Zeus de madera en el siglo vir a. C., y de piedra y ladrillos de barro cocido en el siglo vi a. C. Un mito atribuye el nacimiento de Olimpia al semidiós Heracles (Hércules, para los romanos), que tuvo que superar 12 trabajos para poder acceder al Olimpo como un dios de pleno derecho. Según el relato, al hallarse por la zona, erigió un primitivo altar a Zeus, su padre. Las pruebas deportivas comenzaron a celebrarse en honor al dios supremo de los griegos, en recordatorio de los trabajos de Heracles, que se convierte en modelo de superación física para el hombre.

Otro mito atribuye el origen de los Juegos Olímpicos a Pélope, quien se enfrentó al rey de Pisa, Enómao, en una carrera de carros en la que, si vencía Pélope, obtendría la mano de la princesa Hipodamía (y con ella el reino), pero, si era derrotado, recibiría la muerte. El perdedor, Enómao, moriría, mientras que el ganador, Pélope, sería el nuevo rey y fundaría los Juegos Olímpicos en honor a Zeus. Hipodamía, por su parte, fundaría los Juegos Hereos en honor a Hera, reservados a las mujeres. Violencia, soberanía y género aparecen vinculados en este mito. El motivo de la competición por la mano de una princesa será muy repetido en la mitología griega, apareciendo en las historias míticas de Evecme, Atalanta, Penélope, Yole, Alcestis o Helena. En época histórica encontramos, ya a comienzos del siglo vi a. C., el caso de la competición por la mano de Agariste, hija de Clístenes, rey de Sición.

Sea cual sea su origen mítico, los primeros Juegos Olímpicos oficialmente tuvieron lugar en el año 776 a. C. y se celebraron cada 4 años. A los griegos les servirían como sistema de medición del tiempo calendárico y se prolongarían durante casi 1200 años, hasta su prohibición en el 393 d. C. por el emperador Teodosio I, que había elegido al Cristianismo como la religión oficial y única del Imperio Romano, y en el marco de la prohibición de los cultos paganos. Como los juegos eran en honor de Zeus, no tenían cabida en un Imperio cristiano.

En la Antigüedad, los juegos tenían un valor religioso y cultural, y eran además juegos para la paz y fraternidad panhelénica, esto es, entre todos los griegos. Esta idea de paz y fraternidad persiste hoy, aunque a escala global. Antiguamente, los deportistas participantes tenían un salvoconducto que aseguraba sus vidas en los días anteriores y 
posteriores a los juegos, y durante la celebración en Olimpia, los conflictos bélicos se detenían.

En la segunda mitad del siglo XIx, y en el marco de las excavaciones arqueológicas que se estaban desarrollando en el mundo griego, y especialmente las que tuvieron lugar en esa época en Olimpia, parece que tuvo lugar un renacer clásico, con el aumento del gusto por las historias fantásticas de la mitología griega y también por los deportes y la idea de juegos globales celebrados por los antiguos griegos. Así que, en Atenas, Evangelios Zappas se lanzó a la aventura de intentar resucitar los antiguos juegos, y llegó a celebrar 4, en 1859, 1870, 1875 y 1889, pero no tuvieron mucho éxito, por la falta de apoyo económico, de contactos, de propaganda, poca capacidad de convocatoria y escasa respuesta internacional.

Sin embargo, el intento de Zappas sirvió como precursor del que vendría a continuación, encabezado por el francés Pierre de Frédy, barón de Coubertin, acompañado por su íntimo amigo, el sacerdote jesuita Henri Didon. Coubertin tenía todo lo que le había faltado a Zappas, y por otro lado, Didon le hizo ver la importancia fundamental de los Juegos Olímpicos en el mundo moderno, pues aunque no tuvieran el decidido sentido religioso de la Antigüedad, sí que podrían servir como elementos para intentar buscar la paz y la fraternidad entre todos los pueblos del mundo.

El Comité Olímpico Internacional fue fundado en 1894, y en 1896 tuvieron lugar los primeros juegos de la era moderna, en Atenas. Coubertin dice entonces: «Olimpia y las Olimpiadas son símbolos de una civilización entera, superior a países, ciudades, héroes militares o religiones ancestrales». Por su parte, Henri Didon inventó el lema de los juegos: «Citius, altius, fortius» (más rápido, más alto, más fuerte).

Hay que hacer notar el momento en el que nacen, no solo por la influencia de las excavaciones arqueológicas en Olimpia, sino por el ambiente prebélico que se da en Europa entre las grandes potencias imperiales desde finales del siglo XIx. Se está produciendo una escalada armamentística y con los juegos y la competición entre los países se pretende evitar una guerra. El deporte de competición como sustitutivo de la actividad bélica, como quizás sucediese también en los tiempos la civilización minoica. Y ese carácter pacífico, aunque sometido a una temporalidad y a la religión griega, también estaba en los juegos antiguos.

Los juegos de Atenas de 1896 y los siguientes no lograron su fin último, el de parar una guerra en ciernes, que a la postre sería la que nosotros conocemos como la Primera Guerra Mundial, o la Gran Guerra (1914-1918). Durante la conflagración, se detuvo la celebración de los juegos. Después, siguieron intentándolo y su importancia siguió creciendo, pero se preparaba otro desastre mundial de mayor escala. Es curioso ver que los Juegos Olímpicos de 1936 se celebraron en Berlín, bajo el régimen nazi, y los de 1940 
iban a celebrarse en Tokio, bajo un régimen aliado de los fascismos europeos, pero se suspendieron al comenzar la Segunda Guerra Mundial (1939-1945).

$\mathrm{Al}$ acabar el conflicto, el mundo había cambiado. Dos guerras mundiales tan seguidas habían dejado exhausta a Europa y a ambos lados del mundo surgen ya de forma clara las nuevas grandes potencias: Estados Unidos y la URSS. Se inaugura una etapa de conflictos diplomáticos, tensiones, espionajes, maniobras... y conflictos bélicos mediante terceros en países alejados, generalmente tercermundistas (Corea, Vietnam, Afganistán, Cuba...). Es la Guerra Fría entre el bloque occidental y el bloque comunista. Los Juegos Olímpicos sirvieron, por un lado, para descargar la tensión, pues las pistas y campos de juego se convirtieron en los nuevos campos de batalla directos entre los países de los dos bloques, que convirtieron en cuestión nacional el conseguir mediante sus deportistas mayor número de medallas que las potencias ideológicamente enemigas. Cuando los Juegos Olímpicos se celebraron en Moscú en 1980, los Estados Unidos hicieron boicot y no fueron. La URSS y sus aliados le devolvieron la jugada en los juegos de Los Ángeles de 1984. En 1988 ya había cierta distensión, y poco después, en 1989 y 1990 cayó el Muro de Berlín y se derrumbó el régimen comunista en Rusia, las otras antiguas repúblicas soviéticas y en sus aliadas de la Europa oriental. Los primeros juegos de esa nueva etapa que se abría, sin un conflicto latente, pendiendo cual espada de Damocles sobre la existencia de la humanidad, fueron los de Barcelona en 1992.

Las grandes potencias no han vuelto a luchar guerras directas entre ellas desde la Segunda Guerra Mundial, los conflictos se han reducido (aunque lamentablemente siguen existiendo) y el mundo occidental se ha habituado a vivir en paz interna y los conflictos bélicos se ven como algo lejano. $Y$ en esta civilización supuestamente pacífica, los antiguos héroes de los países (soldados, generales, reyes, conquistadores...) han dado paso a los nuevos héroes de nuestras naciones: los deportistas, los equipos y las selecciones nacionales, mientras que los medios de comunicación de masas se han convertido en los nuevos oráculos.

Ahora es cuando podemos ver en su medida histórica el triunfo del deporte tal y como pudo ser concebido en la civilización minoica y con su valor de paz y fraternidad panhelénica en la antigua Grecia. En nuestra sociedad actual, la idea de recuperación de esos valores por Coubertin y Didon parece haber triunfado.

Sin embargo, decíamos que las raíces clásicas de la importancia del deporte en el mundo actual son dos. Hemos analizado una de ellas, la raíz griega, que como hemos podido ver, es probablemente la parte más positiva del deporte. La otra raíz es la romana. Precisamente fueron los romanos los que asimilaron la tradición griega, transformándola, procediendo a usar el deporte como verdadero espectáculo de masas y como elemento de control social, creando además edificios específicos y de gran tamaño simplemente 
para albergar el mayor número posible de espectadores para estas competiciones: circos y anfiteatros.

La conocida expresión latina «panem et circenses» (pan y circo) hacía y hace referencia a la utilización de estos espectáculos para mantener entretenido al pueblo y desviar su atención de las preocupaciones políticas y del poder. Los romanos inventaron este sistema: hoy en día se sigue aplicando casi hasta el extremo. Entonces se hacía de forma directa; hoy en día ni siquiera resulta necesario asistir físicamente al espectáculo deportivo, pues el constante avance tecnológico de los medios de comunicación de masas hace que el espectáculo llegue a cualquier parte del mundo donde exista una televisión, un ordenador o un dispositivo móvil; y su poder de control social de las masas aumenta exponencialmente. Incluso los edificios hoy utilizados para algunos de estos espectáculos, como los modernos estadios de fútbol o baloncesto, o las plazas de toros, se inspiran en el anfiteatro romano por excelencia: el Coliseo.

¿Pero y el elemento religioso? ¿Se perdió desde la prohibición de los Juegos Olímpicos por Teodosio I? Sin entrar a mencionar aquí algunos aspectos deportivos de otras civilizaciones antiguas, como la egipcia o la celta, en las que el elemento religioso estaba siempre presente, es conocida la relación de los juegos de toros minoicos con el culto al toro que profesaban en Creta; ya hemos mencionado la importancia religiosa de los Juegos Olímpicos y el papel de los dioses griegos, comenzando por Zeus y por Hércules, pero había otros dioses... y también otros juegos en el mundo griego, como los Píticos, los Ístmicos, los Nemeos, los Panatenaicos, etc. -aunque estos últimos no tenían un carácter panhelénico-, y la propia mitología helena incluye igualmente algunos ejemplos de competiciones deportivas, especialmente pruebas físicas, como los juegos homéricos en la Ilíada y en la Odisea; y en cuanto a Roma, todos sus juegos, ya fueran los circenses o los gladiatorios, estaban presididos por los dioses romanos, destacando la particular importancia de una u otra divinidad según el caso, como Sol-Helios en las carreras del circo, o Némesis, en los combates de gladiadores.

Pero, saliendo de la Antigüedad, los ejemplos de la relación entre la religión, el deporte y el espectáculo siguen siendo numerosos: pruebas deportivas -tales como las justas-, como juicios de Dios en el Cristianismo medieval europeo; el fenómeno de las peregrinaciones religiosas a pie, a caballo o en bicicleta, desde la Antigüedad hasta el presente y en distintas religiones; el juego de pelota mesoamericano o tlatchtli, un deporte con connotaciones rituales; el tapa wanka yap de los indios dakota (sioux) en Norteamérica ; el sumo y otros deportes tradicionales japoneses y su relación con el Shintoismo y el Budismo; la larga lista de artes marciales orientales y su relación con tradiciones religiosas y filosóficas como el Taoísmo, el Budismo, el Zen y el Yoga; o en época mucho más reciente, el fenómeno de los «atletas de Cristo» en Brasil y otros países suramericanos,... por citar solo unos pocos ejemplos. Y no solo se podría hablar de rela- 
ciones positivas, sino también negativas, al atender a las manifestaciones contrarias de los representantes de ciertas religiones en contra de determinadas actividades deportivas a lo largo de la historia.

Así que, si bien la suma importancia del deporte y su relación con la religión en las civilizaciones clásicas son hechos que nos ayudan a entender la destacada presencia del deporte en la actualidad, las manifestaciones históricas de esa relación en otras civilizaciones y edades son un objeto de estudio igualmente relevante. Y más allá de los estudios antropológicos y sociológicos, el análisis histórico deberá aportar más luz sobre estos temas para poder desentrańar mejor el pasado al mismo tiempo que se ilumina nuestra comprensión del presente. El objetivo de este monográfico de El Futuro del Pasado es precisamente reflexionar sobre estos temas desde diferentes perspectivas y cronologías para tratar, en definitiva, de entender un poco mejor nuestra propia realidad.

Juan Ramón Carbó

Coordinador del Monográfico
Iván Pérez Miranda

Director de El Futuro del Pasado 
Página intencionadamente en blanco 